\title{
CAUSES OF THE KHILAFIAH (OPINION DIFFERENCES) OF FIQH ULAMA IN ISLAMIC COMMUNICATION
}

\author{
Muhtadin and Rajab Ritonga \\ Universitas Prof. Dr. Moestopo (Beragama), Indonesia. \\ muhtadin42@ymail.com
}

\begin{abstract}
The basic functions of communication are entertainment, amusement, deliver public opinion, social control, critics and educate (provide knowledge). Delivering opinion has the same meaning as creating a dialogue forum among the communities and between the communities and the government. This community service discuss the socialization of "the causes of the khilafian (opinion differences) in islamic communication" which is formed in speeches and discussions as one of the islamic dakwah to understand, believe and to practice Islamic syari'ah and aqidah. Khilafiah litterally means argue, different or dissagree. Basically, the ulama fiqih opinion differences happen because of two things, first: principals differenciation of the legal position, whether it can be taken as the consieration to determine the law or not. Second, principals differentiation about language rules in understanding a nash (Al-Qur'an and Al-Hadits). Therefore in this socialization the writer delivers the causes of the khilafiyah or opinion differences of Ulama Fiqh. This socialization aims to make moslem people understand, respect, appreciate and accept the opinion differences in carrying out the worship rules in Islam.
\end{abstract}

Keywords: Socialization, Khilafiah, Dakwah, Fiqih Opinion

\section{INTRODUCTION}

Khilafiah problem or opinion differences is a problem happens in human life reality. For example touching between husband and his wife, some ulama say that it may cancel wudhu but others say it is not; so as in subuh prayer where some people recite the qunut prayer and others do not, etc. Among those khilafiah problems, some solve them in a simple and easy way, because there is an understanding based on our logical mind, besides, khilafiah problem becomes an obstacle to establish harmony so that it becomes divisive among Muslims, because of the excessive nature of ta'asyubiyah (fanatics), not in accordance with common sense considerations

Differences of opinion (the issue of khilafiah in fiqh), in the field of law as a result of researchers (ijtihad), do not need to be considered as a factor that attaches the position of Islamic law, even on the contrary can provide concessions for people expected by the Prophet, in his hadith:

$$
\text { اختلاف امتى رحمة }
$$

"opinion differences (among) my people is a blessing."

From this hadith, it can be concluded that people can choose freely one opinion among many opinions, not stuck only with one opinion. In this community service, the writer ask the jama'ah to learn carefully the differences causes of ulama fiqh with hope that moslem people can understand, respect and appreciate other people opinions.

Community service in socializing khilafiah can be observed from communication aspect. Generally communication means as an effort to influence, invite and transfer minds at once, idelogy, knowledge, attitude and actions in order to follow an ideology, knowledge, understanding and our actions. By communication, people can transfer what they have to other people or in other words, their action to follow other people minds who invite them.

Hasymi defines communication in islam as a dakwah, an invitation to belive and carry out the Islamic syari'ah and aqidah which have to be believed first.

Dakwah means an invitation, exclamation, calling, it is a way of knowlede teacheing technic and art to attract other people's attention to follow certain ideology and actions. In other words: a way of teaching to influence people through their minds in order to change negative situation into positive situation, transffering the disbelief to faith of Allah SWT, from colonialsm to independence, from ignorance to skill, and others and that is islamic communication. Because all of those actions are meant to achieve a goal in islamic faith.

Difference often happen every time Moslem people do the pillars of islam in term of the worship procedures, for example the wudhu procedures, praying procedures, Ramadhan fasting procdures, Pilgrim procedures, and others. There are differences in pronouncing the intention, most ulama say that intention must be pronounced loudly but some say that it becomes "makruh". This is khilafiah.

The purpose of the community service is to make jama'ah know and understand the causes of ulama fiqh opinion differences so that they can accept, appreciate, and respect those differences in therms of worship procedures. According to the above mentioned background, the writer formulate a socialization problem about 
"what are the causes of ulama fiqh oppinion differences in establishing the Islamic law as an Islamic communication study for the jama'ah of the central jakarta Al-Hikmah Mosque of the Social ministry of the Republic of Indonesia?"

\section{IMPLEMENTATION METHOD}

Method used in this community service is interactive face to face speech, duscussion, and question and answer session. The speeches are delivered as socialization activities done on August 28, 2019 at $09.00-12.00$ at AlHikmah Mosque Social Ministy on Salemba Raya street no. 28 central Jakarta. This activity was attended by the mosque jamaah at around 200 people including the social ministry officers and local people around the mosque.

\section{RESULT AND DISCUSSION}

Khilafiah/ikhtilaf means to disagree, not agree. Meanwhile, according to the terminology of fiqhiyah, khilafiah is a disagreement of opinions among ulama fiqh as a result of ijtihad to obtain and determine a certain legal provision.

Thus the problem of khilafiah is a problem of ijtihad as a result of understanding the source of Islamic law.

Various kinds of reasons have caused differences of opinions among the fuqaha, which in general can be divided into two, namely, First, differences in the establishment of the position of legal sources, whether it can be used as a basis for determining the law or not. Secondly, differences in the establishment of language rules in understanding certain texts (Al-Qur'an and Al-Hadith).

The sources of the legal dispute are the Hadith of the Holy Prophet, Ijma', Qiyas, Istihsan, Mashlahah Mursalah and 'Urf. regarding the position of the Qur'an as a source of law, there is no question from all of its aspects. However, in terms of the Qur'anic texts there can be disagreements, and this is included in the discussion about the second cause. For more details, the following disputes will arise regarding the position of legal sources.

The position of the Hadith as a source of law in general is no longer disputed by the fuqaha. However, their disputes can occur regarding other aspects such as: (1) whether a hadith is delivered or not. According to Sahabat Ali and Ibn Abbas, the wife whose husband died when he was pregnant, he had to undergo the longest iddah. Against the wife is actually exposed to two kinds of iddah, namely iddah as a pregnant wife, that is until giving birth of the baby, and 'iddah as the wife left by her husband, which is four months and ten days. In the case of young pregnancy, of course iddah period will be longer than four months and ten days, but in the case of old pregnancy, this period may be shorter than the four-month ten-day period.

So according to the two sahabat, the wife must add three months and ten days. What prompted the two friends to stand like this is, because they did not hear any hadith from the Messenger of Allah, about the Sabi'ah Alaslamiyah, where the Prophet told him, that his iddah was only to give birth of the baby; (2) Whether people believe or not to a narrator of hadith. As understood, not all narrators of the hadith have the same level of trustworthiness and accuracy and memory. Even some of them have doubts about their honesty, their lack of memory and accuracy or their narratives cause doubts, because the hadith which is revealed is contrary to the provisions of the Qur'an or the famous Hadith. This kind of situation happened in the Sahabat era, namely in the first days of Islam and the period afterwards.

An example is about liakah and place of residence (sukna) during iddah for ex-wife who was divorced ba'in (divorced three times). In this case there are three opinions: The first opinion, from sahabat 'Umar $r$ a which states that the ex-wife who was divorced ba'in got a living and a place to live. The reason is the Word of Allah SWT:

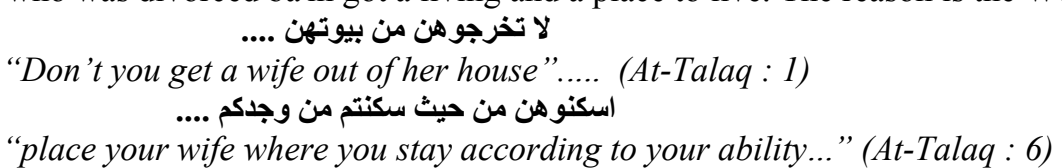

The provisions of the verse apply to all divorced wives. So if a wife has to stay in a former husband's house, then it means he is locked up, and because of this confinement he must earn a living. The second opinion of some other sahabat said that the ex-wife only got a place to live, while for a living did not get it at all. The reason is because of the existence of the inverse law (dalilul-khitab) from the word of Allah SWT in Surah At-Talaq verse 6. which means that if the wife (divorced) is pregnant, then provide a livelihood for her so that she gives birth of her baby. So if so for wives who are not pregnant, they do not get a living.

The third opinion, another sahabat said that the ex-wife did not get anything, both income and shelter. This opinion was also held by Al-Hasan Al-Basri, 'Atha and As-Sya'bi. The reason is the existence of a hadith narrated by a female friend named Fatima bint Qais, who was divorced ba'in by her ex-husband, namely Abu 'Umar bin Hafas. The Fatima complained to Rasulullah SAW, about the inadequacy of guarantees from her ex-husband. Then the Messenger of Allāh, said to him:

$$
\text { ليس للك عليه نفقة }
$$

"He is not obliged to provide for you."

According to another narration of the Prophet, said to him: 
لا نفقة للك و لا سكنى

"There is no income or place to live for you"

After sahabat of Umar r.a. hearing the hadith, he said:

$$
\begin{aligned}
& \text { لا نترك كتاب ربنا و سنة نبينا لقول امرأة لا ندرى لعلها حفظت او نسيت, و فى رواية : لعلها }
\end{aligned}
$$

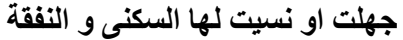

"I will not rule out the book of God (the Qur'an) and the Sunnah of our Prophet just because of the words of a woman, which I do not know, whether she still remembers or is already in shape. According to another history: Maybe he did not know or forget. He is entitled to a place to live and income ".

The same attitude was taken by Siti "Aisyah r.a., the wife of the Prophet SAW, when he asked Marwan, as Governor of Medina, to return the former wife of Yahya bin Sa'id Al-Ash who had divorced to his original place. So Marwan said to Siti 'Aisyah r.a. : Did you not hear the hadith Fatima bint Qais? Then the answer:

\section{لا يضرك الا تذكر حديث فاطمة بنت قيس}

"It's okay if you don't remember the hadith of Fatima bint Qais".

From the information above, we know that for those who do not use the hadith Fatima bint Qais, the reason is that the hadith is considered incorrect. If it were considered right by all of the jurists, certainly there would be no disagreement.

Whether a hadit is valid or not. As a result of many narrations of the hadiths of the Prophet, various conditions of the narator in terms of honesty, accuracy and memory, varying the way of narration of the hadith or not, until or not the tip of the narration of the hadith to the prophet, whether the narator heard from his teacher directly or no, the isolation of the narration of a narrator or someone else narrating the same hadith, and other conditions of the narration of the hadith, as a result of all of that, then arises the division of the Prophet's hadith to the Mutawatir Hadiths and the Ahad Hadith.

Ahad hadith is divided into authentic, hasan and dha'if. With respect to authentic hadiths and hasan, there is no fuqaha that does not use them, but disputes can occur regarding the validity or not of a hadith, where according to someone is considered valid while according to others is considered invalid. This difference is caused by differences in the assessment of matters relating to the aspect of transmission, such as a narrator can be trusted by someone while others do not, or he is considered to hear himself from his teacher, according to the investigation others do not hear themselves, or someone narrator is not from his own group, or the determination of the conditions for the validity of a hadith that is not deemed necessary by others.

For example here is about fasting people who eat because they forget. According to Hanafi, Shafi'i and Hanbali ulama, the person continues his fast without further qadha (repeating fasting). They are based on hadith which are considered authentic, and narrated by Ad-Daruquthni from Abu Hurairah's best friend r.a. from the Prophet Muhammad as follows:

$$
\text { اذا أكل الصائم ناسيا او شرب ناسيا فانما هو رزق ساقه الله اليه و لا قضاء عليه }
$$

"If people who are fasting eat or drink because they forget, then he (eating or drinking) is a provision given by Allah to him and there is no qadha on it".

According to Imam Malik, Ibn Abnu Abi Laila and some Shi'ite Ulama, consider that the hadith is not authentic, therefore fasting people who eat or drink because they forget the fast is canceled and must be qodha.

Division of Dha'if Hadith. The fuqaha divides the Dha'if hadith into two parts, namely the Dha'if hadith which is so weak that it does not give the slightest conjecture to the truth of its contents. This hadith should not be used with the agreement of the fuqaha because taking a law into acoount to the shariah 'must be based on a definite argument (sure) or dalil dhanny (strong suspicion) which shows that the law is the law of God. Second, the Dha'if hadiths are not so weak, and the hadith according to ulama differed in opinion. According to jumhur fuqaha, the hadith may be used, while according to other fuqaha such as the Dhahiri fuqaha, the hadith may not be used, because the hadith raises doubts about its position as the basis of our actions. There are also fuqaha who want to use the hadith dha'if, if there are many ways and there are amplifiers, or if they are in accordance with the results of qiyas.

For example, the condition of kufu (comparability) in marriage, where some fuqaha use it like the Hanafi ulama, while other ulama do not use it, such as Dhahiri ulama. As for the basis is the following hadith:

$$
\text { الا لا يزوج النساء الا الاولياء و لا يزوجن الا من الاكفاء و لا مهر دون عشرة دراهم }
$$

"Remember, not to marry women except for their guardians, they are not married but from comparable men and there are no dowry less than ten dirhams".

The hadith is narrated by Al-Baihaki and Ad-Daruquthni, each from Mubasyir bin 'Ubaid. According to Imam Ahmad that the hadith is Maudhu '(fake), while Imam Hanafi the hadith can be used.

Resistance between two ahadith. Actually between the Shariah laws, there is no opposition to each other, because all of them come from God, both in the form of the Qur'an and Al-Hadith. If we see any resistance / difference between the two hadiths, then this is because we do not know the atmosphere of the passages or the cases in which they were issued, or it is unknown which one was first and which one later or because we do not know the exact meaning (purpose) of the two hadiths. 
It may be that one hadith is related to one event, while another hadith relates to another event. For example about the smell of people who are fasting against his wife. It was reported that the Prophet had forbidden someone who fasted to kiss his wife, and it was also reported that he had allowed others who also fasted to kiss his wife.

Actually between the two narrations there is no resistance, because what is prohibited is a young person who is feared will bring in the next actions again, while the person who is allowed to kiss is an old person, where the matter of smell for him is not feared will bring in the next action that can ruining fasting.

It may be that the apparent resistance is because the retarded hadith actually invalidates the previous hadith, because it has a different atmosphere and circumstances, but both of these hadith reach us without being related to the circumstances and the atmosphere it was issued, and therefore we look for aspects of strength in one of them, famous for the name "tarjih". Because the methods for performing tarjih are not the same, differences of opinion are also unavoidable. One may take one of the hadiths which he considers to be stronger, but other jurists consider strongly the hadith which is considered not strong by the first jurists. Or it may be that both the hadith are used both, where one hadith is for certain circumstances and the other hadith for other conditions. Likewise, among other things, disputes among ulama regarding the hadith as a source of law.

Different opinion because of Ijma'. During the time of Rasulullah SAW, there was no talk about Ijma 'as the source of syariah law', because the source of all syariah law 'was Rasulullah SAW. But after Rasulullah SAW. died, and after the Muslims experienced a legal event that had never been experienced before which they themselves had never asked the law to the Messenger of Allah, then they must somehow seek the legal provisions. For them there is no other way except to have to learn and explore what has been left by the Prophet Muhammad, in the form of the Qur'an and the Hadith in addition to applying the basic rules they have obtained during association with the Prophet. The answers of those who study the law of events are sometimes the same and are unanimous in their opinions, but sometimes their answers also vary. As for the opinion which is still disputed, it is up to the Khalifah to use it or not.

An example here is the problem of dropping divorce three times at a time. Jumhur Ulama Fuqaha, including four Imams of madzhab, said that divorce three times simultaneously fell three as well. Their reasons are the existence of Ijma '(unanimity) on the fall of the three divorces during the khalifah Umar r.a. It is reported that triple divorce was dropped at the same time during the time of the Prophet Muhammad and khalifah Abu Bakr r.a. just fall one, that is to become a raj'i divorce. However, khalifah Umar r.a. consider it necessary to be considered to fall three as well, so that it becomes a teaching for people who like to drop three divorces at once. The actions of the khalifah Umar were then approved by the sahabat and the agreement was considered as Ijma '.

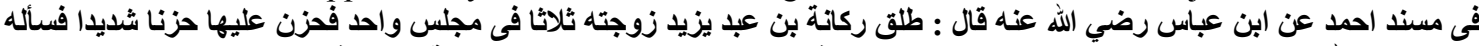

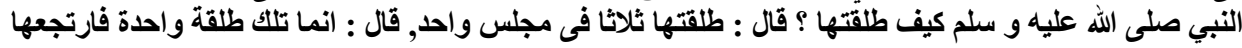
"Ahmad, it is reported that Ibn Abbas r.a. said as follows: Rukanah bin Abdi Yazid divorced his wife three times in one majlis (place), then he became very troubled over his wife. So the Prophet SAW, asked him: How do you divorce him? Rukanah replied: I divorced him three times in one majlis. So said the Prophet SAW: That is only one divorce, then return him ".

Although there is a hadith, but because of the presumption of the occurrence of Ijma 'on the fall of divorce three at the time of Umar r.a. then the fuqaha do not want to accept the hadith and use the provisions that were used before the Umar period r.a. with the reason that the occurrence of Ijma 'on a matter that is different from the provisions of the hadith indicates that there is a text that has canceled the hadith has ended, or because the issuance of the hadith is related to things that would later not be there anymore.

Different Opinion because of Qiyas. With the death of the Prophet Muhammad, the sahabat were forced to squeeze their own brains to know the law of an event being faced. If the incident bears any resemblance to what happened at the time of Rasulullah SAW, then they only have to apply the existing law, and if there is no resemblance, then determining the law are sometimes guided by the general Shari'ah soul, or eliminate narrowness without having the terms and rules of legal determination known in the future. The same methods are also used by the next generation of fuqaha.

But in the future there will be people who use this method not in its place, and as a result, of course, is the imposition of inappropriate laws. Then comes the discussion of the legal arguments, the terms of use and ways to apply them. From here, a dispute arises over a number of legal arguments (sources), and among them is Qiyas.

Differences in the establishment of the use of qiyas certainly cause differences in establishing the law, because what is determined by the qiyas law by qiyas user fuqaha, the law will be returned to the original permissibility by fuqaha who is not a qiyas user.

As an example of differences of opinion because qiyas is, regarding the penalty of drinking. According to Ali's best friend, the punishment is eighty lashes (volumes), because if someone has drunk then he makes slander, while the punishment for defamation is eighty lashes. So drinking is likened to making slander. However, for the Dhahiri fuqaha who do not want to use qiyas, in determining the punishment for drinking they are based on common shari'ah texts, and in this case, they set a "ta'zir" sentence meaning the amount of the punishment for the act left to the discretion of the rulers of a period, not based on certain restrictions. 
Nash Understanding as a cause factor of Khilafiah. The things that give rise to different understandings of the texts (the proposition) in outline can be divided into two kinds, namely the understanding of single words and the understanding of wording (uslub).

The single words are musytarak words, commands and prohibitions, essence and majaz, absolute and muqayyad. The arrangement of words (uslub) which gives rise to different understandings is the exclusion of common words, understanding mukhalafah, fahwul Kitab, ummul muqtadha, istisna after some number of words. Here are the examples:

Musytarak words. Musytarak words mean words that have double meanings. For example the word "qar'un" can mean woman's period and holy, as Allah says:

"The wife who is divorced by her husband must wait for her (middah) three quru"

$$
\text { و المطلقات يتربصن بأنفسهن ثلاثة قروء }
$$

The word "quru" means two, holy and menstrual. Both of these meanings cannot be used together, but one must be taken. According to Imam Malik, Shafi'i and Daud ad-Dhahiri the meaning is "holy". So according to them "iddah divorced wife is three times purification. According to Imam Abu Hanifa the meaning is "menstruation". So according to them 'iddah divorced wife is menstruating three times.

Commands and Prohibition Definiton. In giving instructions / commands by using various forms of words, such as fi'il amar, fi'il mudharik accompanied by lam amar and news sentences that mean commands. In the fuqaha understanding of the form of the order is still disputed, whether it shows obligatory or circumcision, unless there is qarinah. Examples of orders to write a debt agreement and bring two witnesses to the word of God are as follows:

$$
\text { يا ايها الذين امنوا اذا تدينتم بدين الى اجل مسمى فاكتبوه ... و استشهدوا شهاين من رجالكم ... . . }
$$

"O you who believe, if you owe each other with a debt for a period of time, then write down these debts ... and bring forth two witnesses from your man ..." (Q.S. 2: 282)

According to jumhur ulama, the commands are only irshad (guidance) or circumcision, but according to other ulama the command shows mandatory. In giving a ban on syara 'also uses various forms, and the definition is still disputed, whether it shows haram or makruh. This depends on the qarinah. For example a ban on buying or proposing the following hadith:

$$
\text { لايبيع احدكم على بيع احيه ولايخطب على خطبة احيه الا ان يأذن له }
$$

"One of you may not buy on the purchase (offer) of his brother or ask for his brother's proposal unless permitted to him"

Literally and infering meaning words. A word sometimes is used in its literally meaning and sometimes in their figuratie meaning (not the real meaning). This has an effect on differences of opinion for the ulama. As a basic rule, all fuqaha have recognized that as long as they can still use the intrinsic meaning, the meaning of majazi should not be used. However, disputes about the intrinsic meaning can still be possible, also about whether the intrinsic meaning and majazi can both be used together or not.

An example is reading the Fatihah in prayer based on the hadith of the Prophet, as follows:

"There is no (legitimate) prayer for people who do not read the Fatihah" لا صلاة لمن لم يقاً بفاتحة الكتاب

According to some fuqaha, the hadith is interpreted to mean intrinsically, that prayer is considered invalid (does not exist) if it does not read Al-Fatihah. According to Imam Hanafi, the hadith is interpreted in majazi. So what is omitted is its perfection, that is, something prayer will not be perfect if it does not read the Fatihah. If interpreted to the intrinsic meaning it would mean canceling the Qur'anic verse which means: "Then read what is easy for you from the Qur'an". According to the Al-Qur'an, whether Al-Fatihah or not, as long as it is Al-Qur'an, it can be read. So according to Hanafiah scholars by reading just any Qur'anic verses the prayer becomes legal.

Absolute and Muqayyad words. A word is sometimes mentioned in one place with absolute form, the meaning is mentioned without certain restrictions, such as the words "three days". Then the words are mentioned elsewhere in the form muqayyad, meaning to use certain restrictions, so as to reduce the area of application such as "three consecutive days". Examples in this case, for example the words "raqabah" (slave servant) in the letter An-Nisa 'verse 92

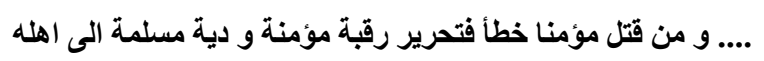

"... Whoever kills a believer by accident will release a slave of a believer and diyat (a fine) which is handed over to his family" (Q.S. 4: 92)

The word servant of the believer shows "muqayyad", while in another letter the word servant of light is mentioned by not mentioning the believer, so "absolute" as in surah Al-Mujadalah verse 3:

\section{و الذين يظاهرون من نسائهم ثم يعودون لما قالوا فتحرير رقبة من قبل ان يتمسا}

"... Whoever kills a believer by accident will release a slave of a believer and diyat (a fine) which is handed over to his family" (Q.S. 4: 92)

The word servant of the believer shows "muqayyad", while in another letter the word servant of light is mentioned by not mentioning the believer, so "absolute" as in the letter Al-Mujadalah verse 3: 


\section{و الذين يظاهرون من نسائهم ثم يعودون لما قالوا فتحرير رقبة من قبل ان يتمسا}

Those who mendhihar (liken the wife to the mahram woman) his wife, then retract his words, then over it frees a slave before the two mix. "Q.S. 58: 3

If we compare between the two verses, it turns out that the law of the two verses is the same, namely the release of the slave, but because the existence of the law is different, because the first verse is about accidental killing, while the second verse is about dhihar to his wife. So according to scholars Hanafiah and Malikiah, between the two verses do not need to be duplicated. So the obligation for unintentional killing is to free the slave of the believer, while the obligation for the oath of the dhihar frees any slave. Whereas according to Shafi'iah ulama, absolute words must be brought to the words muqayyad. So the obligation for Dhihar oaths is to free the servants of believers, as well as unintentional murder.

\section{Mafhum Mukhalafah}

If a law is correlated with a certain nature (condition), or condition or ghoyah (finite) or number, can it be concluded that other cases which do not have a certain nature, or condition or ghoyah or number, have the opposite law (the opposite law) )?

Examples of understanding mukhalafah from the nature is the hadith that says:

"On the goats that he has, there is zakat"

$$
\text { في سائمة الغنم الزكاة }
$$

According to Imam Shafi'i and Hanafi, folding a goat with the word "shepherded" shows that what is not shepherded is not subjected to zakat. So they use the understanding mukhalafah. According to Imam Malik, goats are both shepherded and non-existent. So they do not use the understanding mukhalafah.

\section{Fahwal Khitab / Mahum Muwafaqah.}

Fahwal khitab is the designation of a text on the existence of a law from a case that is mentioned for something that is not mentioned and which is balanced or more important than that stated, for reasons of the existence of the law in both. The extension of a legal matter from the case mentioned to the case that is not mentioned is still disputed by the fuqaha. Imam Shafi'i acknowledged the expansion of the law, while Hanafi did not recognize it. Examples of the release of slaves for unintentional murder, as in the above verse. Based on that verse, the kifarat for those in the form of release of the believer's servant is subject to murder because of accident. But according to fahwal khitab (mafhum muwafaqah) that kifarat is also subject to deliberate murder, because both types of killing both require the means of the fusion of sin, or the same qualifications, namely murder. The difference between the two is that they are only intentionally unintentional, and such differences do not necessarily lead to differences in the determination of kifarat, even in the deliberate murder of the need for a sin smelter even greater, because the sin of unintentional murder only arises from carelessness. Thus the establishment of Shafi'i ulama. According to Hanafiah ulama, Ahmad and Maliki, deliberate killing does not have merit, because the sins between the so-called (accidentally) and the sins that are not called (intentionally) are not the same. The sin of deliberate killing cannot be melted down with worship, which is kifarat, because kifarat can only melt sin which is basically lost. Besides that, kifarat implies punishment (retribution) which is intended as a teaching so as not to repeat what is prohibited.

Istisna after series of words. If after mentioning several legal provisions (a series of words), followed by an exception (istisna), then which legal provisions should be subject to the exception. For example: و الذين يرمون المحصنت ثم لم يأتوا بأربعة شهداء فاجلدوهم ثمانين جلدة و لا تقبلوا لهم شهادة ابدا و اولئك هم الفسقون. الا

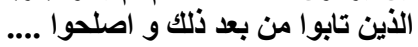

Those who accuse (slander of fornication) good women, then he does not bring four witnesses, then whip them eighty times, and do not accept their testimony forever, and they are wicked, except those who repent ". QS 24: 4

There are three legal provisions here, namely the punishment of volumes, the refusal of testimony and ungodliness. Then there are exceptions, for those who repent. According to some fuqaha, the exceptions are attributed to all three legal provisions, because all three legal provisions are of equal value. Among them is AsShi'bi, he said that those who slander if before being sentenced had ( 80 volumes) had repented, then he was not sentenced to have, received his testimony, and not labeled as a wicked person. Some other fuqaha argued that the exception was attributed to the last two legal provisions. Therefore, what if the person repents, then the punishment has still been handed down, but the testimony can be accepted and qualifications as a fasiq person erased. According to the Hanafiah fuqaha, exceptions to the verse are only attributed to the last legal provisions, that is, which are directly related to exceptions. Thus, the person who slanders was sentenced and had his testimony rejected, even though he had repented. However, with his repentance the fasiq qualifications were erased. These differences of opinion stem from differences in opinion about where to place the exceptions. 


\section{CONCLUSSION}

Broadly speaking, ulama opinions differ due to two things, namely: (1) Differences in the stance on the position of legal sources, whether it can be used as a basis for determining the law or not; (2) Differences in the establishment of language rules in understanding a text of the Qur'an and Al-Hadith. Differences of opinion in the field of law as a result of ijtihad, do not need to be seen as a factor that weakens the position of Islamic law, on the contrary it can be loosened to the people. Differences of opinion that occur in the four schools of thought, namely Imam Abu Hanifah, Imam Maliki, Imam Shafi'i and Imam Ahmad only stem from understanding, consideration, review and ways of taking law from the same sources, namely the Qur'an, Al-Hadith, Ijma ', Qiyas, Istihsan and Maslahah Mursalah. Thus, we follow the opinion of one of the priests not to state that "this opinion is the most correct", because the basis is the same.

\section{REFERENCES}

An-Nawawi, al-Imam Abi Zakariya Yahya ibnu Syaraf ad-Dimasyqiy, Riyadhu al-Shalihin, (1973). Baeirut: Darul Kitab al-'Araby

Hanafi, Ahmad. (1970). Pengantar dan Sejarah Hukum Islam, Bulan Bintang, Jakarta.

Syalaby, Ahmad. (1964). Pembinaan Hukum Islam, Jaya Murni, Jakarta.

Departemen Agama RI. 1987. Al-Qr'an dan Terjemahannya, Yayasan Penyelenggaraan Penterjemahan/Penafsiran Al-Qur'an, Jakarta

Hanafi, A. (1975). Usul Fiqh, Jakarta, Bulan Bintang.

Khalaf, Abdul Wahab, alih bahasa Moh, Zuhri dan Ahmad Qarib, 1994, Ilmu Ushul Fiqh, Semarang, Dina Utama. Muhammad, Syaltout. (1970). Terjemahan Bustani A. Gani, Islam sebagai Aqidah Dan Syari'ah, Bulan Bintang, Jakarta I.

Muhammad bin Ismail al-Kahlaniy, tt, Subul al-Salam, Bandung, Dahlan

Muhammad, Abu Abdullah bin Ismail al-Bukhary, tt, Shahih al-Bukhary, Singapura, Sulaiman Mar'i.

Muhtadin. (2017). Pendidikan Agama Islam Pada Perguruan Tinggi, Grafika Mulia, Boyolali

Muhtadin. (2018). Sosialisasi Yasinan dan Tahlilan dalam Komunikasi Islam, Jurnal Abdi Moestopo, 1(1), 23-29

Sabiq, Sayyid. (1981). Fiqhus Sunnah, Darul Fikar, Libanon. 